\title{
High yield mixotrophic cultures of the marine microalga Tetraselmis suecica (Kylin) Butcher (Prasinophyceae)
}

\author{
Ángeles Cid, Julio Abalde, Concepción Herrero \\ Laboratorio de Microbiología, Dpto. Biología Celular y Molecular, Facultad de Ciencias, \\ Universidad de La Coruña, Campus da Zapateira s/n, 15071, La Coruña, Spain
}

Journal of Applied Phycology March 1992, Volume 4, Issue 1, pp 31-37

DOI 10.1007/BF00003958

\begin{abstract}
The effects of three organic compounds were tested on one of the most used marine micro-algae in the aquaculture of molluscs and crustaceans, Tetraselmis suecica. Studies were made in axenic conditions with yeast extract, peptone and glucose added to the culture medium, each alone, in combinations of two or all together. Medium without any organic compound was used for the control. Cultures containing yeast extract grew best, reaching maximum cell density of $3.79 \times 10^{6}$ and $3.84 \times 10^{6}$ cells $\mathrm{ml}^{-1}$.
\end{abstract}

The organic carbon source affected the biochemical composition. The components most affected were the carbohydrates, with values between $6.5 \mathrm{pg} \mathrm{cell}^{-1}$ in control cultures and $48.5 \mathrm{pg} \mathrm{cell}^{-1}$ in glucose cultures. Protein content ranged between $27.5 \mathrm{pg}$ cell $^{-1}$ in control cultures and $88.6 \mathrm{pg} \mathrm{cell}^{-1}$ in yeast + glucose + peptone cultures. The lipid content changed little. Maximum protein yields were reached in cultures with yeast + glucose and with yeast - glucose - peptone, with values of 24.6 and $28.2 \mathrm{mg}^{-1} \mathrm{~d}^{-1}$, respectively. These values are 22 and 25 times those in control cultures. A maximum carbohydrate yield of $7.9 \mathrm{mg}$ carbohydrate per litre per day was obtained in yeast + glucose + peptone cultures, 27 times that in the control cultures. The maximum lipid yield was obtained with yeast + glucose + peptone and yeast + glucose. Maximum energy values were $308 \mathrm{kcal} 1^{-}$in yeast extract - glucose - peptone cultures and 279 kcal $1^{-1}$ in yeast extract + glucose cultures. Gross energy values in control cultures 
were $24.5 \mathrm{kcal}^{-1}$, but peptone cultures presented the minimum energy value, $22 \mathrm{kcal}$ $1^{-1}$. The yeast extract: glucose ratio in the culture medium was optimized. A ratio 2:1 produced the best yields in cells, protein, carbohydrate and gross energy.

\section{Introduction}

Interest in the mass culture of microalgae is worldwide because their cultivation is a part of the technology of growing marine molluscs, crustaceans and fishes. In many types of aquaculture systems it is necessary to have a large microalgal biomass available as source of food for normal development and growth of the cultured species (De Pauw el al., 1983), Besides their use in aquaculture, microalgae also have commercial value as a source of pigments, vitamins, poly saccharides, sugars, pharmaceuticals and other biologically active compounds (Cohen, 1986; Borowitzka, 1988a; De la Noue \& De Pauw, 1988; Murakami et al., 1988; Richmond, 1990). Furthermore, there are other potential uses of microalgae: waste-water treatment (Oswald, 1988) fertilizers (Cohen, 1986; De la Noue \& De Pauw, 1988), energy source (Borowitzka, 1988b), biocatalysts (Trevan \& Mak, 1988).

Microalgae are phototrophs, but some can also grow heterotrophically (Flynn \& Syrett, 1986). The carbon source is often the limiting factor in microalgal culture systems and it is therefore generally necessary to bubble $\mathrm{CO}_{2}$-enriched air throughout the cultures. However, some freshwater microalgal species can be cultured in mixotrophic conditions and high yields at light intensities lower than those needed in autotrophic cultures have been obtained (Venkataraman et al., 1980; Ogawa \& Aiba, 1981 ; Richmond, 1986, Lee el al., 1989). Energetic costs of aquaculture systems can be reduced using mixotrophic cultures of certain marine microalgae. Carbon can be supplied as organic solutes such as sugars, amino acids or alcohols (Ukeles \& Rose, 1976; Richmond, 1986). Glucose is the most abundant sugar and the most utilized (Droop, 1974; Venkataraman et al., 1980); yeast extract is a good nutrient in cultures of freshwater species of Chlorella (Lee el al., 1989) and peptone has been utilized in mixotrophic cultures of Nilzschia angularis var. affinis (Ogawa \& Aiba, 1981). Taking into account these reports, the effects of these three organic compounds were tested in axenic cultures of one of the most commonly used marine microalgae in the aquaculture of molluscs and crustaceans, Telraselmis suecica (Walne, 1974; Bayne, 1976; Laing\& Utting, 1980; Wikfors, 1986). 


\section{Materials and methods}

Tetraselmis suecica (Kylin) Butcher (Chlorophyta, Prasinophyceae) was isolated from the Ria de Arousa waters (NW of Spain). It was cultured in seawater filtered through a $0.45 \mathrm{I}$ 'm Millipore filter, autoclave at $120{ }^{\circ} \mathrm{C}$ for $60 \mathrm{~min}$ and enriched with $\mathrm{NaNO}_{3} 2 \mathrm{mM}$; $\mathrm{NaH}_{2} \mathrm{PO}_{4}, 100 \mu \mathrm{M} ; \mathrm{ZnCl}_{2}, 1 \mu \mathrm{M} ; \mathrm{MnCl}_{2} ; 1 \mu \mathrm{M} ; \mathrm{Na}_{2} \mathrm{MoO}_{4}, 1 \mu \mathrm{M} ; \mathrm{COCl}_{2}, 0.1 \mu \mathrm{M}$; $\mathrm{CuSO}_{4}, 0.1 \mu \mathrm{M}$; ferric citrate, $20 \mu \mathrm{M}$; thiamine; $35 \mu \mathrm{g}^{-1}$; biotin, $5 \mu \mathrm{g}^{-1}$; $\mathrm{B}_{12}, 3 \mu \mathrm{g}^{-1}$; EDTA,26.4 mM; Tris- $\mathrm{HCl}, 15 \mathrm{mM}$; pH 7.6. Salinity of the seawater was $35 \%$ ond the initial $\mathrm{pH}$ of the cultures was 7.6. Mixotrophic cultures were carried out with the addition of yeast extract, peptone and glucose to the culture medium, either singly, or in combinations of two or three compounds. Concentrations used were: peptone $1.25 \mathrm{~g} \mathrm{l}^{-1}$ glucose $2.5 \mathrm{~g} \mathrm{l}^{-1}$ and yeast extract $5 \mathrm{~g} \mathrm{l}^{-1}$. Cultures without any organic compound in the medium were used as control.

The cultures were grown axenically in triplicate in screw-capped Kimax tubes containing $40 \mathrm{ml}$ of mediull. All cultures were maintained at $18 \pm 1^{\circ} \mathrm{C}$, and $17 \mu \mathrm{mol}$ photon $\mathrm{m}^{-2} \mathrm{~s}^{-1}$ with a dark: light regime of 12: $12 \mathrm{~h}$. An inoculum of $2 \times 10^{4}$ logarithmic phase cells $\mathrm{ml}^{-1}$, was used. Growth was measured in a Bausch and Lomb Spectronic20 colorimeter by recording the absorbance at $530 \mathrm{~nm}$. In the stationary phase, cell density was determined by counting aliquots in a Coulter Counter model DN.

The biochemical composition was determined in the stationary phase. Protein and carbohydrates were measured in the crude extracts obtained after collecting the cells by centrifugation, resuspending them in distilled water and breaking them in an ultrasonic disintegrator. After sonication the extracts were centrifuged again, the pellets were discarded and protein and carbohydrates were measured in the supernatants. Protein was measured by the dye-binding method and carbohydrates by the phenolsuolphuric acid method as described by Kochert (1978a, b). Lipids were measured by a quantitative charring method (Marsh \& Weinstein, 1966). The gross energy of cells under the different conditions was calculated in the stationary phase using the formula of the National Reserach Council (1977):

$$
\begin{aligned}
\mathrm{GE}\left(\mathrm{kcal} \mathrm{kg}^{-1}\right) & =5.72(\% \text { protein }) \\
& +9.50(\% \text { lipid }) \\
& +4.03(\% \text { carbohydrate })
\end{aligned}
$$

Stationary phases, corresponding to maximum biomass production, were compared by an overall multivariate one-way analysis of variance (ANOVA) $(P \leq 0.05)$. 


\section{Results}

Tetraselmis suecica grew in all media tested. Microalgal growth is characterized by a sigmoid or logistic function and the growth curves and their mathematical functions are shown in Fig. I. The form of the logistic growth function was (Schanz \& Zahler, 1981)

$$
y(t) \sim K / 1+B \exp (-r t)
$$

where $y(t)$ represents the absorbance at time $I$ and $K$ its ultimate limiting value ('carrying capacity'). $B$ is a biologically unimportant constant, and its value was calcul ated by the following equation:

$\left(K-y_{0}\right) / y_{0}$. The parameter $r$ is related with growth rate. All the parameters of the equation were fitted by non-linear regression using Marquardt's algorithm.

Maximum cell densities reached in the stationary phase are shown in Table I. Optimal combinations for obtaining better growth and maximum cell densities in the stationary phase were all those including yeast extract (Fig. I): i.e. alone, with glucose or peptone, or with both. Maximum cell densities were $3.84 \times 10^{6}$ cells $\mathrm{ml}^{-1}$ in cultures with yeast

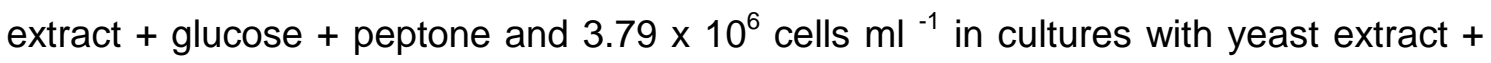
glucose; there was no significant difference between them $(P \leq 0.05)$. The yield in peptone cultures and in glucose cultures was less than that in the control cultures. However, the addition of peptone + glucose improved the yield (Fig. I; Table 1). The organic carbon source also affected the cellular composition (Table I). The cellular component most affected was the carbohydtates, with contents of between $6.5 \mathrm{pg} \mathrm{cell}^{-1}$ in control cultures and $48.5 \mathrm{pg} \mathrm{cell}^{-1}$ in glucose cultures. Protein content ranged

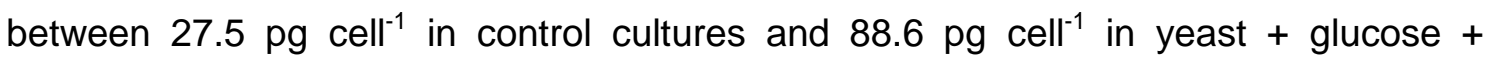
peptone cultures (Table 1 ). The lipid content did not change significantly along the cultures with the different organic carbon sources, ranging from 20.6 to $28.6 \mathrm{pg} \mathrm{cell}^{-1}$

Differences in cell densities and in cell contents resulted in large differences in the yields of protein, lipids and carbohydrates (Fig. 2). Yields of protein (mg $1-1 \mathrm{~d}-\mathrm{I}$ ) in mixotrophic cultures were significantly higher than those in control cultures $(P \leq 0.05)$ (Fig. 2). Maximum protein yields were reached with yeast + glucose and with yeast + glucose + peptone, with values of 24.6 and $28.2 \mathrm{mg} \mathrm{l}^{-1} \mathrm{~d}^{-1}$, respectively; there was no significant difference between these. These values are 22 and 25 times those in control cultures $\left(1.1 \mathrm{mg} \mathrm{l}^{-1} \mathrm{~d}^{-1}\right)$. Maximum carbohydrate yields were obtained in yeast + glucose + peptone cultures, with $7.9 \mathrm{mg} \mathrm{l}^{-1} \mathrm{~d}^{-1}, 27$ times those reached in control cultures. Regarding lipids, we observed three groups among the cultures: ( I) control, 
peptone, glucose, and peptone + glucose cultures, with lipids yields between 0.9 and $1.8 \mathrm{mg} \mathrm{l}^{-1} \mathrm{~d}^{-1}$; (2) yeast and yeast + peptone cultures, with 3.2 and $3.7 \mathrm{mg} \mathrm{l}^{-1} \mathrm{~d}^{-1}$, respectively; and (3) yeast + glucose + peptone and yeast + glucose cultures, with 6.6 and $7.2 \mathrm{mg} \mathrm{l}^{-1} \mathrm{~d}^{-1}$. There are no significant differences within a group, but there are significant differences among the groups $(P \leq 0.05)$. The first group includes the cultures with lower growth, and the third group includes those with higher growth.

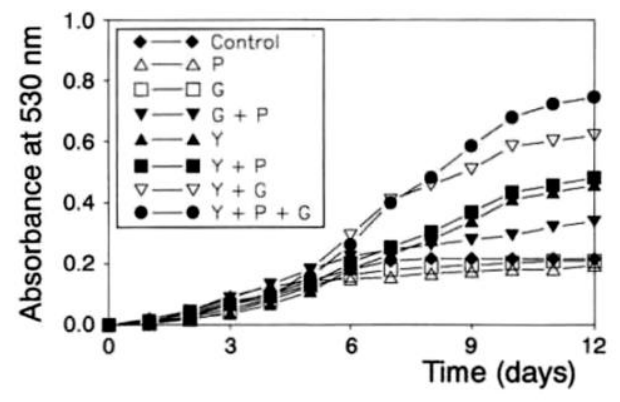

Fig. 1. Growth curves of Tetraselmis suecica in mixotrophic cultures with different organic compounds and autotrophic cultures (Control). Growth yield was measured by absorbance at $530 \mathrm{~nm}$. ( $\mathrm{P}=$ peptone; $\mathrm{G}=$ glucose; $\mathrm{Y}=$ yeast extract $)$.

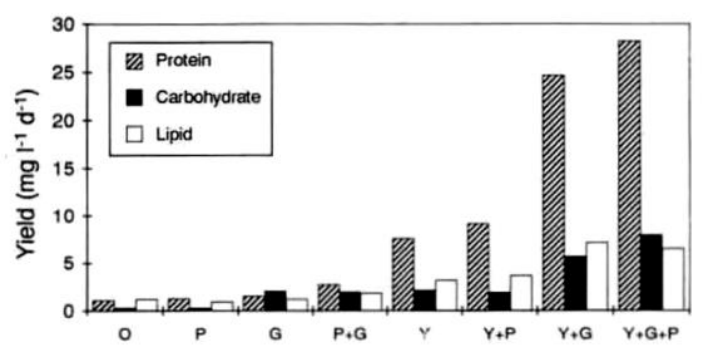

Fig. 2. Yields in different biochemical components $\left(\mathrm{mg} \mathrm{I}^{-1}\right.$ $\mathrm{d}^{-1}$ ) in mixotrophic cultures of Tetraselmis suecica with different organic substrates $(\mathrm{O}=$ control; $\mathrm{P}=$ peptone; $\mathrm{G}=$ glucose; $\mathrm{Y}=$ yeast extract). $(r=0.996)$

$(r=0.990)$

$(r=0.999)$

$(r=0.984)$

$(r=0.998)$

$(r=0.999)$

$(r=0.999)$

$(r=0.999)$

Energy measurements of organic compounds were carried out knowing the composition in protein, carbohydrate and lipid. If we take into account that these microorganisms are used in feeding molluscs, larvae, etc, suspended in liquid medium at a known density, we can calculate the energy of microalgae per litre of culture. Maximum energy values were $308 \mathrm{kcal} \mathrm{I}^{-1}$ in, yeast extract + glucose + peptone cultures and 279 $\mathrm{kcal} \mathrm{I}^{-1}$ in yeast extract + glucose cultures. Gross energy values found in control cultures were $24.5 \mathrm{kcal} \mathrm{I}^{-1}$ but peptone cultures presented the minimum energy value, $22.3 \mathrm{kcal} \mathrm{I}^{-1}$, (Fig. 3).

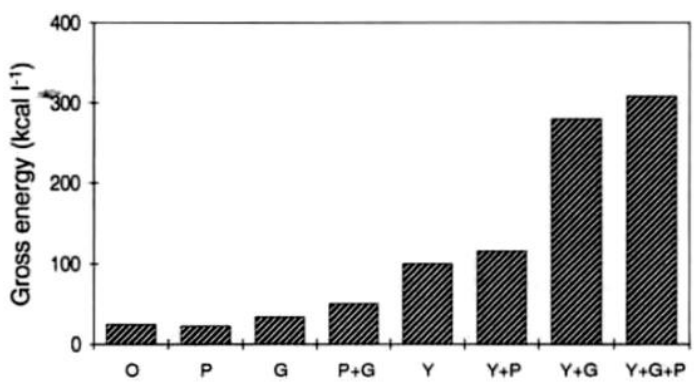

Fig. 3. Gross energy (kcal $1^{-1}$ ) of Tetraselmis suecica in mixotrophic cultures with different organic substrates $(\mathrm{O}=$ control; $\mathrm{P}=$ peptone; $\mathrm{G}=$ glucose; $\mathrm{Y}=$ yeast extract $)$. 
Table 1. Cell density and biochemical composition per cell in the stationary phase in mixotrophic cultures of Tetraselmis suecica grown with different organic compounds $(\mathrm{O}=$ control; $\mathrm{P}=$ peptone; $\mathrm{G}=$ glucose; $\mathrm{Y}=$ yeast extract $)$.

\begin{tabular}{|c|c|c|c|c|c|}
\hline Culture & $\begin{array}{l}\text { Cell density } \\
\left(10^{6} \text { cell } \mathrm{ml}^{-1}\right)\end{array}$ & $\begin{array}{l}\text { Proteins } \\
\left(\mathrm{pg}_{\text {cell }}{ }^{-1}\right)\end{array}$ & $\begin{array}{l}\text { Carbohydrates } \\
\left(\mathrm{pg} \mathrm{cell}^{-1}\right)\end{array}$ & $\begin{array}{l}\text { Lipids } \\
\left(\mathrm{pg} \text { cell }{ }^{-1}\right)\end{array}$ & $\begin{array}{l}\text { RNA } \\
\left(\mathrm{pg} \mathrm{cell}^{-1}\right)\end{array}$ \\
\hline $\mathrm{O}$ & 0.56 & 27.45 & 6.50 & 26.68 & 11.96 \\
\hline$P$ & 0.43 & 39.23 & 8.59 & 27.18 & 16.42 \\
\hline G & 0.52 & 39.73 & 48.48 & 28.60 & 14.17 \\
\hline$P+G$ & 0.75 & 46.20 & 31.79 & 28.20 & 19.62 \\
\hline $\mathrm{Y}$ & 1.76 & 52.79 & 14.87 & 20.55 & 12.90 \\
\hline$Y+P$ & 1.59 & 70.48 & 14.65 & 28.12 & 12.70 \\
\hline$Y+G$ & 3.79 & 78.42 & 18.02 & 22.90 & 13.86 \\
\hline$Y+G+P$ & 3.84 & 88.61 & 25.38 & 20.64 & 20.44 \\
\hline
\end{tabular}

The highest results were obtained in cultures with yeast + glucose + peptone and those with yeast + glucose, without significant differences between them. Therefore, taking the medium with yeast extract + glucose as reference, the improvement in microalgal yields by optimizing the ratio between yeast extract and glucose was studied. For this optimization, and after a previous screening, a minimum yeast extract concentration of $1.25 \mathrm{~g} \mathrm{l}^{-1}$, was used, and four glucose concentrations between 0.08 and $0.625 \mathrm{~g} \mathrm{l}^{-1}$ resulting in yeast extract: glucose ratios (w/w) of $16: I, 8: I, 4: I$ and 2: 1 . Cultures without glucose were used as control. Changes in the yeast extract: glucose ratio in the medium affected the growth of the marine microalgae Tetraselmis suecica (Fig. 4). Significant differences in the cell densities reached at stationary phase were found $(P \leq 0.05)$ (Table 2). Cell density reached in the stationary phase increased as the yeast: glucose ratio decreased. At constant yeast concentration, a correlation between the glucose concentration in the medium and number of cells reached can be established and this is represented by the equation $y=5.52 x+0.98 \quad(r=0.99)$, where $x$ is the glucose concentration in the medium and $y$ the cell density in $10^{6} \mathrm{cells}^{\mathrm{ml}} \mathrm{l}^{-1}$. The optimum ratio for obtaining a maximum cell density was 2: 1 , with $4.34 \times 106$ cells ml-'; this value is significantly higher $(P \leq 0.05)$ than values obtained in the other cultures, with higher yeast: glucose ratios (Table 2). The minimum cell density of $0.93 \times 10^{6}$ cells $\mathrm{ml}^{-1}$, was obtained in control cultures without glucose. Cultures with a yeast: glucose ratio 16: 1 , i.e. a glucose concentration of $0.08 \mathrm{~g} \mathrm{l}^{-1}$ had a cell density of $1.35 \times 10^{6}$ cells $\mathrm{ml}^{-1}$ significantly higher than control. Therefore, the addition of this minimum quantity of sugar produced cell densities 50\% higher than densities reached in the cultures without glucose (Table 2).

The cell composition was less affected by differences in yeast: glucose ratio (Fig. 5). The cell constituents more affected were proteins. A maximum protein content of 56.2 pg cell ${ }^{-1}$ was reached in cultures with a yeast: glucose ratio $4: 1$. Yields in protein increased with the decrease of yeast: glucose ratio, and were highest at the ratio 2: 1 with $19.2 \mathrm{mg} \mathrm{l}^{-1} \mathrm{~d}^{-1}$. This was significantly higher than values obtained in the remaining 
cultures (Fig. 6). Yields of carbohydrates also increased when the yeast extract: glucose ratio decreased. The maximum value was $5.3 \mathrm{mg} \mathrm{l}^{-1} \mathrm{~d}^{-1}$ in cultures with 2: I yeast: glucose ratio. This yield is about 4 times higher than that in the control cultures. Lipid yields varied along the same pattern as carbohydrates, with a maximum value of $9.3 \mathrm{mg} \mathrm{l}^{-1} \mathrm{~d}^{-1}$, (Fig. 6). Energy increased proportionally to the glucose concentration, i.e. gross energy increased when yeast: glucose ratio decreased. Values were between $243 \mathrm{kcal} \mathrm{I}^{-1}$ in yeast: glucose ratio 2:1, and 50.7 in cultures without glucose (Table 2).

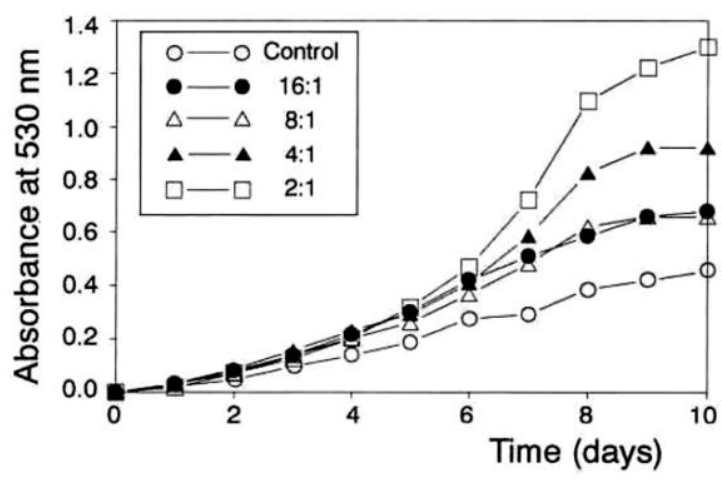

Table 2. Influence of yeast extract: glucose ratios on cellular density in the stationary phase and gross energy in mixotrophic cultures of Tetraselmis suecica.

\begin{tabular}{llc}
\hline Culture & $\begin{array}{l}\text { Cellular density } \\
\left(10^{6} \text { cell ml }^{-1}\right)\end{array}$ & $\begin{array}{l}\text { Gross energy } \\
\left(\mathrm{kcal} \mathrm{1}^{-1}\right)\end{array}$ \\
\hline Control & 0.93 & 50.68 \\
$16: 1$ & 1.35 & 75.57 \\
$8: 1$ & 1.79 & 117.36 \\
$4: 1$ & 2.97 & 221.86 \\
$2: 1$ & 4.34 & 243.76
\end{tabular}

Fig. 4. Growth curves of Tetraselmis suecica in mixotrophic cultures with different yeast extract: glucose ratios. Growth yield was measured by absorbance of $530 \mathrm{~nm}$.

$$
\begin{array}{ll}
\mathrm{y}(t)_{\mathrm{O}}=0.463 /[1+26.235 \exp (-0.590)] & (r=0.997) \\
\mathrm{y}(t)_{16: 1}=0.716 /[1+30.109 \exp (-0.640)] & (r=0.999) \\
\mathrm{y}(t)_{8: 1}=0.768 /[1+29.72 \exp (-0.580)] & (r=0.997) \\
\mathrm{y}(t)_{4: 1}=1.308 /[1+42.6 \exp (-0.548)] & (r=0.996) \\
\mathrm{y}(t)_{2: 1}=1.485 /[1+116.96 \exp (-0.706)] & (r=0.997)
\end{array}
$$

\section{Discussion}

Organic carbon nutrition has been studied extensively in a number of freshwater microalgal species, especially Chlorella and Scenedesmus, which are of interest with respect to biomass production (Ukeles \& Rose, 1976; Richmond, 1986). However this kind of nutrition has less studied in marine species. The type or organic solutes and the light intensity had marked effects on the cultured micro algae. Mixotrophic culture does not stimulate growth at high light intensities (Ukeles \& Rose, 1976). It was for this that experiments were carried out at $17 \mu \mathrm{mol}$ photon $\mathrm{m}^{-2} \mathrm{~s}^{-1}$ light intensity, lower than the saturation level reported for $T$. suecica (Fabregas $C l$ a/., 1985). In the same way, glucose added to C. pyrenoidosa and C. vulgaris cultures had a growth stimulating effect only at light intensities less than saturation (Ogawa \& Aiba, 1981).

Experiments to establish the influence of an organic source of carbon must be carried out in axenic conditions (Neilson et al., 1973). On the other hand, bacteria-micro algae 
interactions may provide better yield than that reached in axenic photoautotrophic cultures (Atlas \& Bartha, 1987). However, the maximum cell densities obtained in these axenic mixotrophic cultures at $\mu \mathrm{mol}$ photon $\mathrm{m}^{-2} \mathrm{~s}^{-1}$ light intensity are three times those obtained in non-axenic autotrophic cultures of $T$. suecica at $215 \mu \mathrm{mol}$ photon $\mathrm{m}^{-2} \mathrm{~s}^{-1}$ light intensity (Fabregas $\mathrm{cl}$ al., 1984). This fact means the use of a light intensity twelve times lower, with the consequent reduction in the energetic costs for the production of the micro algal biomass.

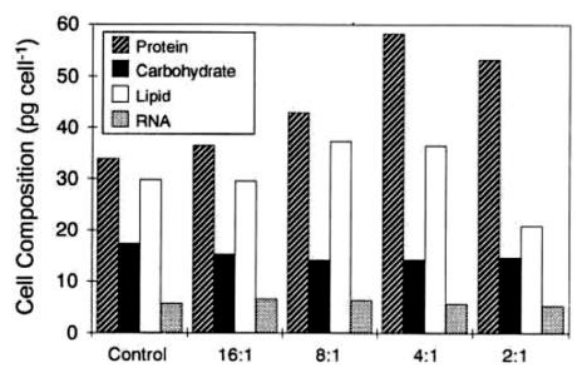

Fig. 5. Biochemical composition (pg cell ${ }^{-1}$ ) in the stationary phase of mixotrophic cultures of Tetraselmis suecica using different yeast extract:glucose ratios.

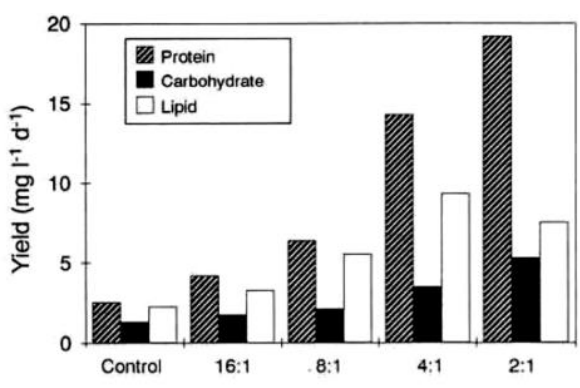

Fig. 6. Yields of cell components ( $\left.\mathrm{mg} \mathrm{l}^{-1} \mathrm{~d}^{-1}\right)$ in mixotrophic cultures of Tetraselmis suecica using different yeast extract:glucose ratios.

Among the different compounds assayed the best results were obtained in all the combinations which included yeast extract. Yeast extract has already been described as a good nutrient in cultures of freshwater species Chlorella (Lee et al., 1989), but its use has not been reported for marine species. Growth in peptone cultures and in glucose cultures was less than that in the control cultures. However, the addition of peptone + glucose improved the growth. This synergistic effect was also been observed for other organic compounds in freshwater micro algal mixotrophic cultures (Ogawa \& Aiba, 1980; Lee et al., 1989).

The best results were obtained in cultures with yeast extract + glucose and yeast extract + glucose + peptone with maximum cell densities of 3.79 and $3.84 \times 10^{6}$ cells $\mathrm{ml}^{-1}$. These results are three times higher than maximum cell density reached in nonaxenic autotrophic cultures of this micro alga, with optimal conditions of salinity Ifnd nutrient concentration and a light intensity of $215 \mu \mathrm{mol}$ photon $\mathrm{m}^{-2} \mathrm{~s}^{-1}$ (Fabregas et al., 1984). Biomass yields increased when the yeast extract: glucose ratio was optimized. Biochemical cell composition was less affected by changes in the yields extract: glucose ratio in the medium than the yeast in biomass. The only affected cell fraction was the protein, whereas carbohydrates, lipids and RNA did not change. Similar results have been reported previously (Becker \& Venkataranlan, 1982), showing a decrease in the protein content of microalgal cells in response to a decrease in the carbon 
concentration in the culture medium. However, the protein fraction was more affected by the carbon compound used than by the yeast: glucose ratio in the medium. Growth and biochemical variability of the marine micro alga Tetraselmis suecica grown with different sources and concentrations of organic carbon compounds can change its nutritive value, with a potential effect on its value as single-cell protein (Fabregas \& Herrero, 1985), or as feed mariculture (Wikfors cl al. , 1984; Fabregas \& Herrero, 1986).

These results all show that mixotrophic cultures results in a higher biomass yield compared with other processes, possible due to the energetic effect of light and organic substrate. Such mixotrophic cultures with high yields and minimum energetic cost can be used to supply the microalgal biomass needed in certain aquaculture systems.

\section{Acknowledgements}

This work was supported by a grant from Dirección General de Investigación Científica y Técnica (DGICYT), Madrid, Spain (n PB 87-0499).

\section{References}

1. Atlas RM, Bartha R (1987) Microbial Ecology, Fundamentals and Applications. The Benjamin/Cummings Publishing Company, Inc. California, 533 pp

2. Bayne BL (1976) The biology of the 'mussel larvae' In: Bayne BL ded.), Marine Mussels: Their Ecology and Physiology. Cambridge U.P., Cambridge, 81-120.

3. Becker EW, Venkataman LV (1982) Biotechnology and Exploitation of Algae. The Indian Approach. Deutsche Gesellschaft für Technische Zusammenarbeit Gmbh, Eschborn, 216 $\mathrm{pp}$

4. Borowitzka MA (1988a) Vitamins and fine chemicals from micro-algae. In: Borowitzka MA, Borowitzka LJ deds), Micro-algal Biotechnology. Cambridge U.P., Cambridge, 153-196.

5. Borowitzka MA (1988b) Fats, oils and hydrocarbons. In: Borowitzka MA, Borowitzka LJ (eds), Micro-algal Biotechnology. Cambridge U.P., Cambridge, 257-287.

6. Cohen Z (1986) Products from microalgae. In: Richmond A (ed.), Handbook of Microalgae Mass Culture. CRC Press, Florida, 421-453.

7. De la Noue J, De Pauw N (1988) The potential of microalgal biotechnology: A review of production and uses of microalgae. Biotech. Adv. 6: 725-770. 
8. De Pauw N, Verboven J, Claus C (1983) Large-scale microalgal production for nursery rearing of marine bivalves. Aquacult. Eng. 2: 27-47.

9. Droop MR (1974) Heterotrophy of carbon. In: Stewart WDP (ed.), Algal Physiology and Biochemistry. Blackwell, Oxford, 530-559.

10. Fabregas, J, Abalde J, Herrero C, Cabezas B, Veiga M (1984) Growth of the marine microalgae Tetraselmis suecica in batch cultures with different salinities and nutrient concentrations. Aquaculture 42: 207-245.

11. Fabregas J, Herrero C (1985) Marine microalgae as a potential source of single cell protein (SCP). Appl. Microbiol. Biotechnol. 23: 110-113.

12. Fabregas J, Herrero C (1986) Marine microalgae as a potential source of minerals in fish diets. Aquaculture 51: 237-243.

13. Fabregas J, Herrero C, Cabezas B, Abalde J (1985) Mass culture and biochemical variability of the marine microalga Tetraselmis suecica (Kylin) Butch with high nutrient concentrations. Aquaculture 49: 231-241.

14. Flynn KJ, Syrett PJ (1986) Utilization of L-lysine and L-arginine by the diatom Phaeodactylum tricornutum. Mar. Biol. 90: 159-163.

15. Kochert G (1978a) Protein determination by dye-binding. In: Hellebust JA, Craigie JS (eds), Handbook of Phycological Methods. Physiological and Biochemical Methods. Cambridge U.P., Cambridge, 95-97.

16. Kochert G (1978b) Quantitation of macromolecular components of microalgae. In: Hellebust JA, Craigie JS (eds), Handbook of Phycological Methods. Physiological and Biochemical Methods, Cambridge U.P., Cambridge, 189-195.

17. Laing I, Utting SD (1980) The influence of salinity in the production of two commercially important unicellular algae. Aquaculture 21: 79-86.

18. Lee HY, Lee SY, Park BK (1989) The estimation of algal yield parameters associated with mixotrophic and photoheterotrophic growth under batch cultivation. Biomass 18: 153-160.

19. Marsh JB, Weinstein DB (1966) Simple charring method for determination of lipids. J. Lipid Res. 7: 574-576.

20. Murakami M, Makabe K, Okada S, Yamaguchi K, Konosu S (1988) Screening of biologically active compounds in microalgae. Nippon Suisan Gakkaishi 54: 1035-1039.

21. National Research Council (1977) Nutrient requirements of warmwater fishes. National Acad. Press, Washington D.C., 78 pp

22. Neilson AH, Blankley F, Lewin RA (1973) Growth with organic carbon and energy sources. In: Stein JR (ed.), Handbook of Phycological Methods. Culture Methods and Growth Measurements. Cambridge U.P., Cambridge, 275-285.

23. Ogawa T, Aiba S (1981) Bioenergetic analysis of mixotrophic growth in Chlorella vulgaris and Scenedesmus acutus Biotech. Bioeng. 23: 1121-1132.

24. Oswald WJ (1988) Micro-algae and waste-water treatment. In: Borowitzka MA, Borowitzka LJ deds). Micro-algal Biotechnology. Cambridge U.P., Cambridge, 305-328.

25. Richmond AE (1986) Microalgaculture. CRC Crit. Rev. Biotech. 4: 369-438. 
26. Richmond AE (1990) Large scale microalgal culture and applications. Prog. Phycol. Res. 7: 269-330.

27. Schanz F, Zahler U (1981) Prediction of algal growth in batch cultures; Schweiz. Z. Hydrobiol. 43: 103-113.

28. Trevan M, Mak A (1988) Immobilized algae and their potential for use as biocatalysts. Trends Biotech. 6: 68-73.

29. Ukeles R, Rse WE (1976) Observations on organic carbon utilization by photosynthetic marine microalgae. Mar. Biol. 37: 11-28.

30. Venkataraman LV, Nigam BP, Ramanathan PK (1980) Rural oriented freshwater cultivation of algae in India. In; Shelef G \& Soeder CJ deds), Algae Biomass. Production and Use. Elsevier/North Holland Biomedical Press, Amsterdam, 81-95.

31. Walne PR (1974) Culture of Bivalve Molluscs. 50 Years' Experience at Conwy. Fishing New Books, Furnham, $173 \mathrm{pp}$

32. Wikfors GH (1986) Altering growth and gross chemical composition of two microalgal molluscan food species by varying nitrate and phosphate. Aquaculture 59: 1-14.

33. Wikfors GH, Twarog JW, Jr, Ukeles R (1984) Influence of chemical composition of algal food sources on growth of juvenile oysters, Crassostrea virginica. Biol. Bull. 167: 251-263. 